\title{
Response of black pepper varieties for propagation by serpentine layering
}

\author{
A Thapa*, S Datta \& U Rai \\ Department of Vegetable and Spice Crops, Uttar Banga Krishi Viswavidyalaya \\ Pundibari, Coochbehar, West Bengal - 736165, India. \\ ${ }^{*}$ E-mail: adimangarthapa@gmail.com
}

Received 30 September 2021; Revised 16 November 2021; Accepted 20 November 2021

\begin{abstract}
In the present study response of light black pepper verities for propagation through serpentine layering was studied. Verities showed significant variations with respect to growth attributing parameters, survivability and numbers of layers per year. Maximum survivability $(93.00 \%$ and $88.33 \%$ ) at 30 and 90 days after cutting was found in Panniyur-1. Maximum planting material production per year was achieved in Panniyur-1 (51.17) which was higher than the rest of the varieties but was statistically at par with Panniyur-2 (50.50) and Pournami (50.17). These three varieties may be considered for higher production of planting materials through serpentine layering method.
\end{abstract}

Keywords: planting material, serpentine layering, varieties, survivability

Black pepper (Piper nigrum L.) (Piperaceae) is one of the most popular spices in the world. Black pepper can be propagated through seeds and vegetative methods. Owing to its heterozygous nature, seedlings do not breed true to type and known to have long prebearing period. Hence, vegetative propagation is commercially adopted. The conventional methods adopted for establishment of black pepper have the disadvantage of false sprouting and poor root development, coupled with high disease incidence which eventually leads to poor establishment. A novel propagation technique in black pepper is the serpentine method (Thankamani et al. 2004). In this method the rooted cuttings kept in polythene bags are trailed horizontally and each node is pressed into the polythene bags with potting mixture arranged one after another with midribs of bamboo pegs made into V shape. Once 10-15 nodes get rooted in the bag, first 10 will be separated by cutting at the inter nodes. The cut ends will be pushed back into the potting mixture and kept in shade for further growth. Serpentine method can be followed throughout the year, it is 
simple, cheap and quick and suited to small and marginal farmers. Recovery percentage is higher compared to rapid multiplication technique (Nybe et al. 2016). Availability of adequate quantity of quality planting material of the different improved varieties for large scale multiplication is one of the major constraints faced by the pepper industry in increasing the productivity of pepper in India. With this in view, the present investigation was carried out to study the response of different black pepper varieties for propagation through serpentine layering.

The present investigations were carried out at the Instructional Farm, Uttar Banga Krishi Viswavidyalaya, Pundibari, Cooch Behar, West Bengal during the year 2016-17 and 201718. Experiment were conducted to study the response of different black pepper varieties on the production of planting material through serpentine layering under terai zone of West Bengal in a Completely Randomized Design (CRD) with three replications. Eight black pepper varieties (viz; Panniyur-1, Panniyur-2, Panniyur-3, Panniyur-6, Panniyur-7, Pournami, Panchami and Subhakara) layered in a media comprising of soil + sand + FYM @1:1:1 were used. For preparation of mother plant, semihardwood cutting from runner of 3 years old black pepper verities were prepared and kept in a poly bag filled with potting mixture for rooting. As the layer produced nodes, poly bags of size $15 \mathrm{~cm} \times 10 \mathrm{~cm}$ filled with potting mixture were kept under each node for producing roots and this process was repeated continuously as the vine grew. Terminal buds were nipped off and cutting of rooted nodes were taken and separated individually once each mother plant produced fifteen rooted nodes. Observation regarding shoot length, root length, number of roots, number of leaves, survival percentage, numbers of planting material production at 30 days and 90 days after cutting of layers were recorded. Mean data on all the recorded parameters were statistically analyzed. Data were analyzed statistically using the procedure of Gomez \& Gomez (1984).
The growth parameters and survival percentage were observed at two stages i.e., at 30 days and 90 days after cutting of layers and number of planting material production was recorded by counting number of plants obtained during the year (Table 1 and 2).

Among the different varieties, significant variations were recorded with respect to all the observed parameters mentioned above. Maximum shoot length $(12.65 \mathrm{~cm}$ at 30 days and $26.44 \mathrm{~cm}$ at 90 days after cutting of layers) was recorded in Panniyur-1, meanwhile lowest shoot length was recorded in Panniyur-7 $(8.04 \mathrm{~cm}$ at 30 days and $16.63 \mathrm{~cm}$ at 90 days after cutting of layers). Number of leaves at 30 days (6.01) and 90 days (8.98) after cutting of layers was highest in Panniyur-1 followed by Panniyur-2 (5.53 and 8.54). The variety Panniyur-7 recorded the lowest number of leaves at 30 days (3.78) and 90 days (6.54) which was on par with number of leaves produced by Subhakara (3.92 and 6.75) at 30 days and 90 days after cutting of layers. The variations in shoot parameters among varieties might be due to the genetic characteristic of varieties. Similar result was also reported by Prajapati (2005) regarding number of leaves in Panniyur-1 black pepper variety (8.87 at 90 days after planting of cutting) grown in Navsari, Gujarat.

Experimental findings revealed that different varieties responded significantly to the root parameters of planting material. Maximum root length of $7.06 \mathrm{~cm}$ and $23.75 \mathrm{~cm}$ was recorded in Panniyur-1 at 30 and 90 days after cuttings of layers, respectively which was statistically on par with Panniyur-2 and Pournami (Table 1). Whereas, Panniyur-7 recorded lowest root length of $6.50 \mathrm{~cm}$ and $17.58 \mathrm{~cm}$ at 30 and 90 days after cutting of layers, respectively. Similar reports were also recorded by Akshay et al. (2018) in Panniyur-1 under Karnataka condition. Results with respect to number of roots revealed that maximum numbers of roots (6.85 and 8.96) at 30 days and 90 days were recorded in Panniyur-1 followed by Panniyur-2 
Table 1. Shoot and root parameters of planting materials of different black pepper verities produced through serpentine method.

\begin{tabular}{ll|l|l|l|l|l|l|l}
\hline & \multicolumn{2}{c|}{ Shoot length $(\mathrm{cm})$} & \multicolumn{2}{c|}{ Number of leaves } & \multicolumn{2}{c|}{ Root length $(\mathrm{cm})$} & \multicolumn{2}{c}{ Number of roots } \\
\cline { 2 - 8 } Variety & $\begin{array}{l}\text { 30 days } \\
\text { after } \\
\text { cutting }\end{array}$ & $\begin{array}{l}\text { 90 days } \\
\text { after } \\
\text { cutting }\end{array}$ & $\begin{array}{l}30 \text { days } \\
\text { after } \\
\text { cutting }\end{array}$ & $\begin{array}{l}90 \text { days } \\
\text { after } \\
\text { cutting }\end{array}$ & $\begin{array}{l}30 \text { days } \\
\text { after } \\
\text { cutting }\end{array}$ & $\begin{array}{l}90 \text { days } \\
\text { after } \\
\text { cutting }\end{array}$ & $\begin{array}{l}30 \text { days } \\
\text { after } \\
\text { cutting }\end{array}$ & $\begin{array}{l}90 \text { days } \\
\text { after } \\
\text { cutting }\end{array}$ \\
\hline Panniyur-1 & 12.65 & 26.44 & 4.63 & 8.39 & 12.36 & 23.75 & 5.95 & 8.73 \\
Panniyur-2 & 11.25 & 25.11 & 4.28 & 7.45 & 12.02 & 22.83 & 5.33 & 8.36 \\
Panniyur-3 & 8.80 & 20.41 & 3.73 & 6.37 & 9.91 & 19.42 & 3.42 & 6.90 \\
Panniyur-6 & 9.45 & 22.03 & 3.72 & 6.61 & 10.28 & 20.27 & 3.50 & 6.95 \\
Panniyur-7 & 8.04 & 16.63 & 3.43 & 5.48 & 8.93 & 17.58 & 2.50 & 5.58 \\
Pournami & 10.60 & 24.88 & 3.96 & 6.84 & 11.20 & 22.71 & 4.15 & 7.63 \\
$\begin{array}{l}\text { Panchami } \\
\text { Pubhakara }\end{array}$ & 10.13 & 23.27 & 3.87 & 6.73 & 10.79 & 21.71 & 4.20 & 7.35 \\
$\begin{array}{l}\text { C.D. } \\
\text { (P=0.05) }\end{array}$ & 2.15 & 2.65 & 0.73 & 1.22 & 1.77 & 2.55 & 0.64 & 0.72 \\
\hline
\end{tabular}

Table 2. Survival percentage and planting material production, performance of black pepper varieties.

\begin{tabular}{llll}
\hline \multirow{2}{*}{ Variety } & \multicolumn{2}{c}{ Survival percentage $(\%)$} & $\begin{array}{l}\text { Number of planting } \\
\text { materials produced } \\
\text { in a year }\end{array}$ \\
\cline { 2 - 4 } & 30 days after cutting & 90 days after cutting & 51.17 \\
Panniyur-1 & $93.00(9.72)$ & $88.83(9.58)$ & 50.50 \\
Panniyur-2 & $92.17(9.64)$ & $87.67(9.45)$ & 48.00 \\
Panniyur-3 & $87.17(9.51)$ & $82.67(9.22)$ & 49.00 \\
Panniyur-6 & $88.67(9.56)$ & $83.33(9.27)$ & 45.17 \\
Panniyur-7 & $85.50(9.42)$ & $80.67(9.07)$ & 50.17 \\
Pournami & $91.17(9.62)$ & $86.33(9.37)$ & 49.67 \\
Panchami & $89.33(9.58)$ & $84.33(9.32)$ & 47.00 \\
Subhakara & $86.33(9.47)$ & $81.67(9.13)$ & 2.71 \\
C.D. (P=0.05) & 0.05 & 0.07 & \\
\hline
\end{tabular}

*Values in (parentheses) indicate the square root transformed values (Gomez \& Gomez 1984). 
(6.00 and 8.34) at 30 days and 90 days after cutting of layers while, Panniyur-7 recorded the lowest number of roots (2.28 at 30 days and 5.58 at 90 days. Prajapati (2005) also reported the number of roots in Panniyur-1 (9.40 at 90 days after planting of cuttings) grown under Gujarat conditions.

Resultsregardingsurvivalpercentageofcuttings elucidated that maximum survivability $(93.00$ and $88.33 \%$ ) at 30 and 90 days after cutting was found in Panniyur-1 while Panniyur-7 recorded lowest survival percentage of 85.50 and 80.67 respectively. Maximum planting materials per year was produced by Panniyur-1 (51.17) which was higher than the rest of the varieties but was statistically at par with Panniyur-2 (50.50) and Pournami (50.17). On the other hand, among the different varieties Panniyur-7 recorded lowest planting material production (45.17). Variations with respect to survival percentage and number of planting material production among the different varieties might be due to varietal characteristics. Though the preliminary observation on survivability at 30 days after cutting showed a higher value, it reduced at 90 days which might be due to the conditions prevailed during the experiment that favored nursery diseases. Khandekar et al (2004) reported at par result regarding survival percentage $(89.77 \%$ at 90 days after cutting of layers) and number of planting material produced (54.16) in Panniyur-1 propagated through bamboo split method in Dapoli, Maharashtra.

Based on this experiment, it could be concluded that Panniyur-1, Panniyur-2 and Pournami are best suited for production of quality planting material of black pepper through serpentine layering method of propagation.

\section{References}

Akshay K R, Narayana S M, Raviraj S, Ganapathi M \& Thippeshappa G N (2018) Efficacy of media and growth regulator on rooting of black pepper (Piper nigrum) cuttings. J. pharmacogn. phytochem. 3: 413417.

Gomez K A\& Gomez AA(1984) Statistical Procedure for Agricultural Research. pp. 1-340. Second Edn. International Rice Research Institute John Wiley and Sons. New York.

Khandekar R G, Haldankar P M, Pande V S, Joshi G D, Bagade D S, Malve D B, Bhagwat N R, Rangwala A D, Jambhale N D \& Ramana K V (2004) Studies on rapid multliplication of black pepper (Piper nigrum L.) on soil mound. J. Spices Arom. Crops 13 (1): 34-36.

Mani A \& Kabiraj A (2019) Export potential of spices and its value-added products. Agriculture and Food: E-Newsletter 1 (8): 338-347.

Nybe E V, Raj M N \& Kandiannan K (2016) Planting material production technology in vegetatively propagated perennial spice crops - black pepper, nutmeg, cinnamon, cambodge and tamarind. Advances in planting material production technology in spices. Proceedings of National Seminar on Planting Material Production in Spices pp 2-18. Directorate of Arecanut and Spices Development, Kozhikode, Kerala.

Prajapati N H (2015) Effect of plant growth regulators on rooting of cutting in black pepper (Piper nigrum L.) cv. Panniyur-1 under protected cultivation. M.Sc. Thesis, Navsari Agriculture University Gujarat.

Thankamani C K, Srinivasan V, Hamza S, Kandiannan K \& Mathew P A (2007) Evaluation of nursery mixture for planting material production in black pepper (Piper nigrum L.). J. Spices Arom. Crops 16 (2): 111-114. 